\title{
İLGINÇ YÖNLERIYLE SULTAN MELIKŞAH
}

\section{ALİ SEVIM}

Büyük Selçuklu Devleti'nin azamet devrinin hükümdarı olarak tarihe geçmiş olan Sultan M e li kşa h, 6 Ağustos 1055'de dünyaya gelmiştir. Daha küçük yaşlarda iken babası Sultan Alp A rsla n 'la birlikte sefere çıkmak suretiyle, devletin fetih planları çerçevesinde, görev yapmaya ve dolayısıyla da tecrübe kazanmaya başlamıştı. Onun çıktığı seferler sırasında kazandığı başarılar nedeniyle Sultan Alp A rs la n, son derecede sevinmiştir ${ }^{1}$. Daha sonra Alp Arslan, oğlu M elikşah'ı Karahanlı hanedanına mensup olan C elâli ye Terken Hatun'la Merv kentinde evlendirdi. A lp A rsı a n, Üstyurt ve Mangışlak'a sefer düzenledikten sonra Nişabur'a yakın Râdgân kentinde büyük bir tören düzenleterek "Oğlu M eli kşa h 'ı veliaht yaptğını" açıkladı ve Selçuklu emîrlerine "Kendisinden sonra M e li kş a h'ı sultan olarak tanımaları hususunda teker teker ant içirdi, hil'atler verdi ve "Yönetimine $\mathrm{M}$ e li kş a h ' 1 atadığ kendi adından sonra onun adının da hutbelerde okutulmasını" emretti ve onun emrine 15 bin kişilik bir askerî birlik de verdi, daha sonra da M elikşah' '1, omuzunda hükümdarlık ve tâbiilik simgesi olan eyer örtüsü (gâşiye ${ }^{2}$ ) olduğu hâlde, ata bindirip onun önünde birkaç adım yürüdü. Oğlu Melikşah hakkındaki bu isteğini tekrarlamak amaciyla Alp Arslan, Malazgirt Savaşı'na başlamadan önce, eşine ve veziri N i za mülm ülk'e "Savaşta şehit olursam Büyük Selçuklu Devleti tahtına oğlum M elikşa h geçmelidir" dedi. Sultan, bu isteğini Berzem kalesi kumandanı H â r e z m li Yu s u f tarafindan ağır bir biçimde yaralanıp ölmeden önce, beraberindeki veziri ve kumandanlarına söylediği vasiyeti ${ }^{3}$ arasında "oğlu $M$ elikşa h '1 Sultan ve N i z a m ülm ülk 'ü de onun veziri olarak tanıyıp onlara itaat et-

${ }^{1}$ Bu konuda daha ayrıntulı bilgi için bk. İ. Kafesoğlu, Sultan Melikşa h Devrinde Büyük Selçuklu İmparatorluğu (İstanbul 1953), s. 9-12; A. Sevim-E.Merçil, Selçuklu Devletleri Tarihi, Siyaset, Teşkilât ve Kültür (Ankara 1995), s. 76-77.

${ }^{2}$ Bk. E. Merçil, "Gâşiye ve Selçuklular'da Kullamılışına Dâir Bazı Örnekler", Yusuf Hikmet Bayur Armağanı, Ankara 1985, s. 321-323

${ }^{3} \mathrm{Bu}$ vasiyetin ayrıntısı hakkında bk. Ali Sevim, "Sıbt İbnü'l-Cevzî'nin Mir'âtü'z-zaman Fî Tarihi'l-Âyan Adlı Eserindeki Selçuklularla İlgili Bilgiler, II., Sultan Alp Arslan Dönemi" Belgeler, Türk Tarih Belgeleri Dergisi, cilt XIX, sayı 23, s. 49-50; A. Sevim-E. Merçil, a.g.e., s. 74. 
melerini" de söylemiştir. M e l i k ş a h'ın veliahtlığı'nın Abbasî halifesi el$\mathrm{Ka}$ i m Bi em rillah'ın da onaylaması gerektiği için sultan Alp Arsla n, halifeye bir elçi göndererek bu hususta ondan izin istedi. Sultanın bu isteğini uygun bulan halife, Amîdüddevle b. Cüheyr'i hil'atlarla birlikte bir tevkîi, bu sıralarda İsfahan'da bulunan M elikşah'a göndermiş, o da veliahtlık iznini içeren tevkîi ve hil'atları ona vermiştir ${ }^{4}$. Sultan A l p A r s l a n 'ın ölümü (24 Kasım 1072) üzerine de babasının vasiyeti doğrultusunda devlet erkânı ve komutanlar, M eli kşa h'ı Büyük Selçuklu Devieti tahtuna sultan olarak oturttular; onun sultanlığı halife el-K a i m Bi em rilla h tarafindan da resmien onaylandı. Böylece Selçuklu sultanı olan 20 yaşındaki M elikşah, huzuruna gelen devlet erkânına, $\mathrm{Ni}$ z a m ülm ülk'ün "Ey sultan hadi konuş" demesi üzerine "Sizin benden büyüğünüz benim babam, ortancanız kardeşlerim, küçükleriniz de benim oğullarımdır" demek suretiyle onların kalplerini hos tutup kendine bağlamaya çalışt, daha sonra da hep birlikte Merv'e giderek babasının cesedini, dedesi $C$ a ğ $\mathrm{r}_{1}$ B e y'in mezarının yanına defnettiler ${ }^{5}$.

\section{Kavurt Bey'in Son İsyanı ve Sultan Melikşah}

Sultan M elikşa h, Selçuklu tahtuna çıktıktan sonra ülke içindeki huzursuzlukları önleme ve Selçuklu sınırlarını koruma hareketlerine başladı. Özellikle amcası Kirman hâkimi Kavurt Bey'in, kardeşi Alp Ars la n'ın ölümü üzerine kendisine "Ben, büyük kardeş, sen küçük olan oğuldan daha çok Selçuklu tahtın. lâyıkım" diyerek isyana kalkışması üzerine Sultan M eli kşah, beraberinde veziri $N$ i za m ülm ülk, ordusu, kumutanlanı ve Selçuklu vasalı Arap emîrleri olduğu hâlde, K a vu r t B e y'e karşı harekete geçip Hemedan yakınlarında onunla savaşa başladı (15 Nisan 1073); Kavurt Bey, yenilgiye uğrayıp Hemedan dağlarına kaçmasına rağrnen ele geçirildi. Bu arada $\mathrm{M} \mathrm{elikşah,} \mathrm{Hemedan'a} \mathrm{geldi} \mathrm{ve} \mathrm{veziri} \mathrm{Ni}$ z a m ü l m ü k 'ün de etkisiyle "K a vu rt'un derhal öldürülmesini" emretti. Bir ara yakalanıp kendisine teslim edilen emîr $\mathrm{S}$ a v ţe k i ${ }^{6}$ tarafindan yaya olarak sultanın huzuruna getirilen $\mathrm{K}$ a vu r t B e y, ona saygısını göstermek amacıyla önünde yere eğilip onun elir i öptü. Bunun üzerine sultan, ona "Ey amca, böyle yorgun ve perişanlık do dyısıyla ne hâle gelmişsin! Bana karşı giriştiğin bu isyan hareketinden hiç 'utanmıyor musun? Sen, kardeşin olan

\footnotetext{
${ }^{4}$ Bu hususta ayrıntı için bk. I. Kafesoğlu, ı.g.e., s. 12-13; A. Sevim-E. Merçil, a.g.e., s. 77.

${ }^{5}$ Bu konuda bk. A. Sevim, a.g.mak., s. 1-2

${ }^{6}$ Bk. E. Merçil, "Emîr Savtegin", Tarih Enstitüsü Dergisi, sayı 6, İstanbul 1975, s. 63 - 74.
} 
babam Alp Arslan'ın ölümü dolayssıla bir yas günü düzenlemediğin gibi, onun kabrine örtülmek üzere bir örtü bile göndermedin, halbuki yabancılar dahi onun ölümü dolayısıyla yas tuttular, sen ise bir kardeş olarak onun vasiyetini bir tarafa atarak şenlik yapıp eğlendin. Fakat U l u T a n rı, senin bu kötü hareket ve davranışlarının karşılığını işte sana böyle verdi" dedi. K a vur t B ey ise sultanın bu sözlerine cevap olarak "T a n r r'ya ant olsun ki ben, sana karşı asla harekete geçmek istemedim, ancak senin askerlerin bana, gece, gündüz mektuplar gönderip 'Acele kendilerine gelmemi' bildirdiler. İște bu nedenle ben, U l u T a n rı'nın benim hakkımda takdir buyurup yerine gelmesini istediği şey sebebiyle bu isyan harekâtuna giriştim" dedi $^{7}$.

Sıbt'ın eserinde (Mir'âzü'z-zaman), Sultan Melikşah - Kavurt B e y ilişkileri hakkında şu ilginç kayıtlar yer almaktadır:

Sultan M e liks a h, amcası Kavurt Bey'in bulunduğu yeri haber alınca onu yakalaması için birisini gönderdi. Bir tepe üzerinde oturmakta olan sultan, yiyecek istedi ve kendisine hemen getirilen bu yiyecekleri vasal Arap emîrleri Müslim b. Kureyș, İbn Mezyed ve İbn Verr a m'ı çağırtarak onlarla birlikte yedi. Daha sonra sultan, atına binmişti ki tam bu sırada, yakalandıktan sonra atından indirilen ve başındaki külâhı alınıp sultanın yanına getirilen Kavu r $\mathrm{t}$ B e y'e sultanı ululaması için "Yeri

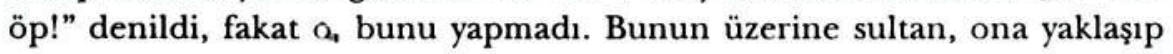
boynuna sarıldı ve "Ey amca, sen çok uzak bir yerden geldin, atına bin ve bizimle gel!" dedi ve hemen de oradan ayrild. Emîr S a v te kin de kendisine teslim edilen $\mathrm{K}$ a vu r t B e y'i alarak kendi özel çadırına götürüp:göz altuna aldı. Bu sırada Kavurt Bey, Sultan M e li ks a h'a ulaştırılmak üzere şunları söyledi: "Bundan sonra ülke ve hükümdarlıkla asla ilgilenmeyeceğim, sultana muhalefet yoluna gitmeyeceğim. Bütün mallarım, kent ve kalelerim ve kölelerim sultanın olsun. Ben, bir mescit köşesinde oturup dünyadan göç edinceye kadar T a n r ı'ya yalvarıp yakarmakla meşgul olarak gece, gündüz zincire bağlı bir hâlde kalayım, böylece tek başıma olup T a n rı fikrinden uzak kalmayayım. Beni öldürtmek suretiȳle Selçuklu hanedanını mahvetme ve benim hakkımda $\mathrm{N}$ i z a m ü l m ül k 'ün sana söylediği söze ve ettiği tavsi-

${ }^{7}$ Bk. A.Sevim, "Sıbt İbnü'l-Cevzî'nin M:r'âtü'z-zaman Fî Tarihi'l-âyan Adlı Eserindeki Selçuklularla İlgili Bilgiler, III., Sultan M eli $\$$ a h Dönemi" Belgeler, Türk Tarih Belgeleri Dergisi, cilt XX, sayı 14, s. 3; Ahmed Bin Mahm ıd, Selçuk-Nâme I, hazırlayan E. Merçil, İstanbul 1977, s. 118-119; aynca bk. A. Sevim-E.Merçil, g.e., s. 80. 
yeye kulak asma ve bana Türklere yakışacak şekilde davran! Ben babanın ölümünden beri sarf ettiğin bütün paraları sana vereceğim. Ülkemi sana teslim edip Suriye, ya da Hicaz'a gideceğim". Çok geçmeden Hemedan'a götürülüp E b û $\mathrm{H}$ âş i m el - C â fer î̀nin evinde hapsedilen $\mathrm{K}$ a v u r t B e y, kendisine gönderilen bir $K_{l} p c ̧ a k$ tarafından boğazına yayının kirişi geçirilip öldürüldü (Nisan/Mayıs 1073) ${ }^{8}$.

Kavurt Bey'in özellikle vezir Nizamülmülk'ün sultan üzerindeki sürekli etkisi sonucunda öldürülmesini haber alan Selçuklu ordusundaki askerler, $N$ izam ülmülk'ü yüzüne karşı lânetleyerek bağırıp çağırdılar, hattâ ordudan ayrılıp başka tarafa çekildiler ve ona "Sultan A l p A rs la n, böyle mi vasiyette bulundu? Halbuki o, Kavurt Bey'e belirli bir miktar para ile Kirman ve Fars'ın verilmesini ve kendi eşi Seferi yye H a tu n 'la da evlenmesini vasiyet etmişti" dediler. Daha sonra askerler, ülkede birçok şeyleri yağmalayıp ele geçirdiler. Askerlerinin bu tutum ve davranışlarından endişeye kapılan Sultan Melikş a h'a veziri Ni$\mathrm{za} \mathrm{m}$ ü $1 \mathrm{~m}$ ü $\mathrm{lk}$, "Bu duruma karşı sen mi önlem alacaksın, yoksa ben mi?" deyince sultan "Tabii ki sen" dedi. Bunun üzerine $\mathrm{N}$ i z a m ü $1 \mathrm{~m}$ ül k, bu askerlere para ve 1 ktâlar verdi, böylece onlar, sultan ve $\mathrm{N}$ i z a m ülmül k'e karşı olan olumsuz tutum ve davranışlarından vazgeçip sükûnet buldular ve orduya geri döndüler. Sultan, vezirinin bu başarısı üzerine onun ıktâlarına, aralarında Tus kentinin de bulunduğu yeni ilâveler yapt; ayrıca ona hil'at giydirip çeşitli armağanlarla "Atabek" unvanını ${ }^{9}$ da verdi ${ }^{10}$.

\section{Sultan Melikşah'ın Oğlu Davud'un Ölümü ve Sultanın İlginç Durumu}

Sultan M e li kşa h'ın hayatında en çok üzüntü duyduğu olay, eşi T e rken H a tu n'dan olan oğlu D a vu d'un 12 Mayıs 1082'de İsfahan'da ölümüdür. Bu sebeple sultan, daha önce hiç görülmemiş şekilde son derecede çok acı çekti, hattâ birkaç kez kendini öldürme girişiminde dahi bu-

${ }^{8} \mathrm{~K}$ a v u t B e y'in isyanı, yakalanıp, öldürülmesi hakkında bk. A. Sevim, a.g.makl., s. 4-5; E. Merçil, Kirman Selçukluları (İstanbul 1980), s. 45-63 (Bu eserde çeşitli kaynak ve araştırmalardan yararlanılmak suretiyle oldukça ayrıntılı bilgiler verilmiştir); $\mathrm{K}$ a vu r t B e y'in öldürülmesinde de uygulanan hanedan mensuplarının öldürülmesi sırasında kanlarının akıtulması yasağı hakkında bk. M.F. Köprülū, "Hanedan âzasının idamında kan dōkme memnûiyeti", Türk Hukuk Tarihi Dergisi (1941/42), I, 1-9. Bu töre'nin değişik bir uygulaması hakkında bk. A. Sevim, Suriye ve Filistin Selçuklular Tarihi, Ankara 2000, 3. Baskı. TTK. Yay., s. 83; İ. Kafesoğlu, a.g.e., s. 20-23; A. Sevim-E. Merçil, a.g.e., s. 78-81.

9 Eski ve yeni $T u ̈ r k$ lehçelerinde "Baba" anlamina gelen ata ile beg (Bey, emir) sōzcüklerinden oluşan Atabek hakkunda bk. M.F. Köprülü, $\dot{I} A$. "Ata" mad. ve bu maddedeki "Atabeğ".

${ }^{10}$ Bk. A. Sevim, a.g.makl., s. 5, not nr. 6'daki eserler; İ. Kafesoğlu, a.g.e., s. 26-27. 
lundu, fakat kendisinin ileri gelen yakınları, ona engel olmak için onun boynuna sarılıp yanından hiç ayrılmadılar, çünkü onun sabır ve dayanma gücü son derecede zayıflamışu. $O$, hep oğlunu koklayıp duruyor, bu nedenle onun cesedinin yıkanmasına engel oluyordu. Yeme ve içmeyi de bırakan sultan, sürekli olarak giysisini çekiştirip duruyordu; kendisini teselli etmek isteyenleri dinlememek için kaldığı yerin kapılarını kapaturdı. Bu arada Türkmenler, Türk matem töresi gereğince Sultanlık Sarayı'nda toplanıp saçlarını, başlarını yoldular, Saray'daki kadınlar, hizmetkârlar ve diğer Saray mensuplarının kadınları da onlara katılıp aynı şeyleri yaptılar. Selçuklu ülkesindeki halk da yedi gün süreyle evlerinde ve sokaklarda yas tuttular, atlarının alınlarındaki kâkülleri kestiler, eyerlerini ters çevirdiler ve üzerlerine karalar sürdüler. Bu yasla ilgili olarak İsfahan'dan Bağdat'a gönderilen bir mektupta "Benim bu mektubum, bir saatte üzüntüden alt-üst olan bir ülkeden geliyor. Ben, böyle bir olaya şimdiye kadar hiç tanık olmadım" denilmiştir.

Oğlunun ölümünden bir ay geçtikten sonra ava çıkan sultan, bir kağıt parçasına şu ilginç yazıları yazmıştır:

"Ey oğlum D a vu d! Sensiz ava çıkum, senden ayrılmamın bana verdiği sıkıntı ve senden uzak kalmamın getirdiği bir yalnızlık içindeyim. Böylece ben, feleğin seni benden aldığı, bu sebeple gecelerimi uykusuz bıraktığı, hayatımı berbat ettiği, ciğerimi parçalayıp üzüntümü ve sıkıntımı arturdığı için ağhyorum. Hadi bana, benden ayrıldıktan sonraki durumunun nasıl olduğunu haber ver! Ölüm, seni değiştirdi mi? Mezar kurtları senin vücudunu ne yaptı? Toprak, yüzüne ve gözlerine ne yaptı? Şu anda sen de benim gibi üzüntülü müsün? Seni ne kadar çok özlüyorum, senin için ne kadar üzülüyorum ve acı duyuyorum. Vâh senin yokluğuna vâh." Sultanın bu acıklı ve ilginç sözlerinin yazılı olduğu kâğıt parçası vezir $\mathrm{Ni}$ z a m ü l m ül k'e götürülüp verildi, o da bunu okuyunca hüngür hüngür ağlamaya başladı ve derhal ileri gelen devlet adamlarını yanına çağııı onlarla birlikte $\mathrm{D}$ a vu d'un mezarına giderek bu kağıdı kabre karşı okudu. Bunun üzerine onlar, hep birlikte feryat ve figanlar edip ağladılar. Bu sıralarda Selçuklu ülkesinde de sanki $\mathrm{D}$ a vu d, yeni ölmüş gibi, daha önce tutulan yaslar tekrar edildi. Ayrıca Halifelik veziri A mî̀düdde vle, Halifelik Saray'ndaki Selâmlık'ta üç gün süreyle yas tutup taziyeleri kabul etti' ${ }^{11}$.

${ }^{11}$ D a v u d 'un ölümü hakkında bk. A. Sevim, a.g. makl. "III., Sultan M elikşa h Dōnemi", s. 45-46; Ahmed Bin Mahmud, I, s. 139-141. Bu hususla ilgili araşurmalarda Krş. O. Turan, Selçuklular Tarihi ve Türk-İ́slâm Medeniyeti, Ankara 1965, s. 150; İ. Kafesoğlu, a.g.e., s. 201 'deki not nr.8'de son derecede az ve yetersiz bilgiler yer almışur. 


\section{Tekiş'in İkinci İsyanı ve Sultan Melikşah'ın İginç Davranışlan}

Bilindiği üzere Sultan M elikş a h'ın kardeși Belh ve Toharistan bölgesinin vasal yöneticisi olan $\mathrm{T}$ e kiş, isyana girişmişse $(1081 / 82)$ de başarılı olamayınca $\mathrm{Melikşah'ın} \mathrm{huzuruna} \mathrm{gelip} \mathrm{af} \mathrm{dileğinde} \mathrm{bu-}$ lunmuştu. Fakat o, daha sonra Sultan M e li kş a h'ın Musul yörelerinde bulunduğu sıralarda, ikinci kez sultana karşı isyana başladı (1084/85). Bu konuda öteki ilgili kaynaklarda yer almayan ilginç bilgiler, $\mathrm{S}_{\mathrm{l}} \mathrm{b} t \mathrm{t}$ 'in eserinde (Garsunni'me Muhmmed b. Hilâl es-Sâbi'in kaybolması sebebiyle bugün elimizde bulunmayan Uyûnü't-tevârîh adlı eserinden naklen) kaydedilmiştir. Bu kayıtlara göre Sultan M eli kş a h, Musul'da bulunduğu sıralarda $\mathrm{T}$ e $\mathrm{k}$ i ş hakkında kendisine şu haberler ulaşturıldı:

T e k i ş, isyana başlayıp harekete geçerek Horasan'daki Mervürrûd'a geldi ve kenti tahrip ederek halkın mal ve paralarını yağmalatu, daha sonra da yine Horasan'daki Mervüşsâhican'a gelerek hile ile şehrin kapısını açturdı, böylece şehre giren $\mathrm{T}$ e ki ş, burada da üç gün sürekli olarak halkın mal ve paralarını yağma ile kadınlara tecavüz ettirdi. Bu arada $\mathrm{T}$ e ki ş ve adamları, Ramazan'da şehrin Ulu Camii'nde içki içtiler ve kâfirlerin bile hoş görmeyeceği kötü şeyler yaptular, ayrıca kenti de tahrip ettiler. Daha sonra Tekiş, Sultan Melikşah'ın nâibi Mesut b. Yâhız etTürkm a n̂̂'nin içinde bulunduğu Serahs'a yöneldi. Bunu haber alan M e s u t, çok sağlam surları olan, bu nedenle kolay kolay ele geçirilemeyen kent kalesine çıkıp savunma hazırlıkları yaptı. Kaleyi günlerce kuşatan T e kiş, M e s u t 'a bir takım hileli haberler gönderdi, fakat $\mathrm{M}$ e s u t, ona "Güya sen, Sultan M elikşah'a ait bayraklar açıyorsun" cevabını gönderdi. Kuşatmayı sürdüren T e k i ş, kale surlarına karşı mancınıklar kurdurup savaşı sürdürmekte iken "Sultanın Rey kentine geldiğini ve kendisinin isyana devam ile savaşuğını haber aldığını" öğrendi. Bu arada Selçuklu ordu komutanları, sultana "Orduyu Hâsların komutasında T e ki ş'e karşı sevkedip kendisinin de arkadan bizzat harekete geçmesini" bildirdiler. Bunun üzerine davullar, camuzlara yükletildi; bunlar, altı günde Nişabur'a ulaşular. Bu arada da Sultan M e li kş a h, M e s u t'a bir mektup gönderip "Davul sesini falan vakitte duyunca askerlerinle davulların önüne çık, biz de onlann arkasından geliyoruz" dedi. Fakat bu sırada $\mathrm{T}$ e k i ş'in öncüleri, sultanın bu mektubunu M e s u t'a getiren casusu yakalayıp T e ki ş'e getirdiler. Mektubun kapsamına vâkıf olan T e kiş, korku ve dehşete kapıldı ve acele olarak alabildiği kadar gerekli eşyalarını topladı, geri kalanlarını da ateşe verip kale 
kuşatmasından ayrılarak Merv'e geldi, fakat halk kent kapısını yüzüne kapatup onunla savaşmaya başladılar ve onun burada bıraktuğı askerlerinden bir bölümünü öldürdüler. Öte yandan $\mathrm{M}$ e $s$ u t b. Yâ hı z, Serahs'a ulaşan B o z a n'ın öncü kuvvetlerine gelip katıldı. Böylece bu Selçuklu kuvvetleri, T e ki ş'in peşine düşüp onun bütün hareketlerini yakından gözetlemeye başladılarsa da ona karşı herhangi bir saldırıya geçmediler. Bu arada Belh'e ulaşan Tekiş, mal ve yiyecek maddelerini almak için burada ikamete başladı, fakat bu sıralarda Sultan M eli kşa h da Belh'e yaklaşmıştı. Bunun üzerine o, Venenc kalesine çıkıp sığındı ise de sultanın kendisini izlemesi sebebiyle buradan ayrılarak bu yöredeki bir otlağa gelip konaklamaya başladı. M e l i k s a h'ın emîri A r t u k B e y de hayvanlarını otlağa salan bura sahipleriyle birlikte bulunuyordu. Bu arada buradaki dar bir geçide kuvvet yerleştiren $\mathrm{T}$ e kiş, beraberindeki emîrleri de Venenc kalesinin çevresine yerleştirdi. Öte yandan Sultan M elikşa h, atuna binip oradaki dar geçidi yukarıdan görebilen bir dağın tepesine çıktı ve buradan, $\mathrm{T}$ e kiş'in bulunduğu yere ulaşılabilmesi kuvvetle muhtemel olan bir yer görüp tespit etti. Bu arada sultan, T e k i ş'in bağışlanması amacıyla kendisine gelen Gazne hâkimi İ b r a h i m b. M e s u t'un elçisine "Biz, şu an bulunduğumuz yerden çekilecek olursak bu kez size karșı askerî harekâta başlarız; çünkü senin emîrin, T e ki ş'i bize karşı isyana kışkırttı" dedi. Bunun üzerine elçi sultana, benim emîrim "Ben, sultanla aramızda olan ahde Gazne'den vazgeçip halkını ve mallarını Hindistan'a nakletmek zorunda kalsam da, sâdık bulunuyorum ve bu ahdimi devam ettiriyorum. Seninle savaşmaktan T a n r 1, beni korusun. Böylece ben, sana itaat ile tâbi olmam dolayısıyla senin kalbindeki benim hakkımda olan olumsuz şeyler ortadan kalkar" dedi. Elçinin bu sözleri üzerine sultan, ona "T e ki ş için emîrinizle aramızdaki dostluğu ve yakınlığı asla bozmak istemeyiz" dedi. Öte yandan T e ki ş'in ordusunda, çok kötü ve yok olma durumuna düşmeleri sebebiyle kaynaşmalar başladı. Bu nedenle askerler T e k i ş'e karşı fikir ve niyetlerini değiştirdiler. Bu durumu anlayan T ekiş, esasında hile yapmak, fakat görünüşte iyi ve hoş görünmek amacıyla sultana bir elçi gönderdi. Önce vezir N i z a mülm ülk'e, sonra da sultana gelen bu elçiye sultan, 'T ekiş'ten bir elçinin, ya da bir mektubun Gazne hükümdarına gönderilmesinden korkup çekindiniz ve sizin hakkınızda hiç kimse ona hitap etmeye cesaret edemez" dedi. Bunun üzerine elçi, $N$ i z a m ü $1 \mathrm{~m}$ ü l k'e gelip " $T$ e ki ş, bütün yetkilerini sana vermiş ve işlerinin yürütülmesini sana bırakmışur" dedi ve T e ki ş'in şu sözlerini de ona aynen nakletti: "Eğer sen 
uygun görürsen ben, sultandan bana bir güven geldikten sonra gider, kendimi sultanın önüne atarım ve elimde bulunan bütün kaleleri ona teslim ederim, çünkü bu kaleler, aramızda vahşet ve kötülüğe sebep oluyor. Ben, bütün bu söylediklerimi kesinlikle aynen yerine getiririm". Elçinin naklettiği T e ki ş'in bu sözleri üzerine $\mathrm{N}$ i z a m ü $1 \mathrm{~m}$ ü $1 \mathrm{k}$, sultanın yanına gitti ve T e ki ş'in elçisini haber verdi, sultan da ona "Şu an, benim yanımda T e ki ş'in emîrlerinden birisi var, bu, bize yeterli bir durumdur. Eğer T e ki ş, kendi memleketinde oturmak isterse o zaman işler yoluna girer ve kaleler kendisine teslim edilir, böylece de ona olan lütuf ve ihsanımız daha çok arturılır ve istediği şey hususunda bana ant içtikten ve senin ve benim tarafımdan istediği şeye güven duyulduktan sonra da hemen benim huzuruma alınır, yok eğer huzuruma gelmekten korkup çekinecek olursa o zaman ben, ona kendi ülkemizde başka bir yer veririm ve elinde bulunan kaleleri bize teslim edip verdiğim o yere gidinceye kadar ona yolu açarım. Eğer o, Toharistan'ı isterse orayı da ona veririm. Benim bundan başka ona hiçbir söz ve cevabım yoktur. Bunu, $\mathrm{T}$ e k iş'in elçisine bildir ve ona 'Bu hususların birisinden dönecek olursa onun boynunu vurdururum' de" dedi. Bu siralarda bir rastlant eseri olarak sultanın emîrlerinden birisi, kapıya yakın bir kalenin alt tarafındaki patika yoldan giderken $\mathrm{T}$ e ki ş'in sarayın içinde sarhoş bir durumda bulunduğunu gördü ve ona saldırdı ise de adamları, onu koruyup kurtardılar, bunun üzerine $\mathrm{T}$ e kiş yukarıya kaleye çıktı. Çok geçmeden $\mathrm{T}$ e ki ş'in sultana gönderdiği elçi, bir süre sonra yeniden geldi ve ona "Ne için geldin?" denilince o da "Sultanın T e ki ş için rızasını almaya geldim" dedi. Bunun üzerine vezir $\mathrm{N}$ i z a $\mathrm{m}$ ü $1 \mathrm{~m}$ ü $\mathrm{l}$ k, elçinin elini tutup sultana götürdü. Sultan onu görür görmez "Ne için geldin?" deyince elçi, "Âdil melikimiz diyor ki 'Ben kaleleri asla teslim etmem, ben, dağın tepesinde olurum, sen de dağın öteki tepesinde olursun, aramızda da vâdi olur, böylece karşılıklı olarak konuşur anlaşırız. Sen, bana Herat'ı verir, bunun için bana Hâce-i B u z u r g N i z a m ü l m ü l k'ü gönderir, onunla bu hususları kararlaştırırız. Ben Mü sli m b. Ku reyş'ten daha aşağı bir insan değilim.'" Elçinin bu sözleri üzerine sultan, gazaba gelip âdeta çılgına döndü ve "Elçinin derhal boynunun vurulmasını" emretti. Bunun üzerine $\mathrm{N} \mathrm{i} \mathrm{-}$ $\mathrm{z}$ a m ü $\mathrm{lm}$ ü $\mathrm{lk}$, ayağa kalkıp yer öptü ve elçinin öldürülmemesi için sultana yalvarıp yakardı. Esasında bu durum, $\mathrm{N}$ i z a $\mathrm{m}$ ü $1 \mathrm{~m}$ ü $\mathrm{l}$ k'e çok zor geldi ve acı verdi, çünkü o, bu sorunu, sultan $\dot{I}_{c ̧ k i}$ Meclisi'nde iken acele olarak ona götürüp arz etmişti. N i z a m ü $1 \mathrm{~m}$ ü l k'ün geldiğini öğrenen sultan, âdeti olduğu üzere, ona saygısı sebebiyle “İçki Meclisi'nin derhal 
kaldırılmasını" emretti. T e kiş'in elçisinin öldürülmemesi sorununu çözmeyi başaramayan $\mathrm{N}$ i z a m ü $\mathrm{l}$ m ü $\mathrm{l}$ k, buna son derecede üzüldü. Bu arada sultan, "Askerlerin elçinin çevresini kuşatmalarını, daha sonra da kuvvetli bir darbeyle boynunun vurulmasını" emretti. Sultanın bu emri, derhal yerine getirildi, elçinin cesedi de T e ki ş'e gönderildi. Daha sonra Sultan M e l i kş a h, T e ki ş'i ele geçirmek amacıyla ordusuyla hareket geçti, emîr B o z a n'ın komutasındaki sultanın öncü kuvetleri Serahs'a gelip burada bulunan $\mathrm{M}$ e s u t b. Yâh $ı$ z, B o z a n ve P o r s u k'un kuvetleriyle birlikte Tekiş'i izlemeye başladılar, sonunda Venenc kalesine sığınmış olan T e ki ş'i buradan zorla indirdiler (2 Ekim 1085), gözlerine mil çekilen T e ki ̧̧ Dâmegân'daki Fîrûzkûh kalesine gönderildi, böylece o, ölünceye kadar orada tutuklu kaldı ${ }^{12}$.

\section{Sultan Melikşah'ın Kuzey-Suriye Seferi Sırasındaki İlginç Davranışlan}

Sultan M elikşa h'ın Kuzey-Suriye'ye gitmek üzere ${ }^{13}$ Isfahan'dan ayrılıp Nizam ülmülk'ün oğlu Mü eyyidülmülk'ün yönetimindeki Tekrit üzerinden Musul'a hareket etti. Yolu üzerinde bulunan bir Arap kabilesine mensup temsilciler, sultana gelerek "Elcezire'de oturmakta olan Arapların kendilerine saldırmamaları hususunda lütfedip kendilerine güvence vermesini" dilediler, sultan da onlara bir $o k$ vererek "Bunu, Arapların obalarına götürüp onlara vermelerini" bildirdi ${ }^{14}$. Bu arada bir bedevî Arap, sultana gelip "Ey âlemlerin sultanı, bir askeriniz benim mızrağımı aldı" deyince sultan, daima beraberinde bulunup kendisini koruma görevi yapan Çavuşiyye (Savuşiyyen=Çavuşlar)'ye ${ }^{15}$ "Bunu araşturmalarını" emretti. Çavuşlar, kısa sürede elinde bedevî Arabın mızrağı bulunan o askeri sultanın huzuruna getirdiler, sultan da "Bu askerin elinin kesilmesini" emretti ve bedevî Araba da "Bu kesik eli mızrağının ucuna koy

${ }^{12} \mathrm{~T}$ e kiş'in ikinci isyanı ve sonu hakkunda, $\mathrm{G}$ a r s u $\mathrm{n} \mathrm{n} \mathrm{i} \mathrm{'} \mathrm{m}$ e 'den naklen $\mathrm{S}$ ı b t 'ta verilen bu ayrıntılı ve ilginç bilgiler, òteki ilgili kaynaklarda yer almadığı gibi ilgili araştırmalara da yansıtulmamışur. Krş. İ. Kafesoğlu, a.g.e., 58-59; A. Sevim-E.Merçil, a.g.e., s. 114-115; Türk Ansiklopedisi (TA.) "Tekiş. Şihabüddevle" mad.; Sıbt'daki bilgiler, Ahmed b. Mahmud tarafindan da nakledilmiştir. Bk. I, s. 144-149.

${ }^{13}$ Sultan M e li ks a h 'in Kuzey-Suriye seferi ve daha sonra cereyan eden olaylarm ayrıntısı hakkında bk. A. Sevim, a.g.e., s. 127-132; Sıbt'daki bilgiler Ahmed b. Mahmud tarafından da nakledilmiştir, bk. I, s. 144-149.

${ }^{14} \mathrm{Bu}$ konuda bk. O. Turan, "Eski Türklerde Okun Hukukî Bir Senbol Olarak Kullanilması", Belleten (1945), IX/35, s. 305-18.

${ }^{15}$ Çavuşiyye hakkunda bk. A. Sevim-E. Merçil, a.g.e., s. 507. 
ve Araplara güven verip hoşnut etmek için onların obalarında dolaşur" dedi, bedevî de sultanın bu emrini aynen yerine getirdi.

Gerçekten ilgili kaynak ve araştırmalara yansımayan bu ilginç olay, Selçuklu yönetiminin tâbilerine karşı ne derecede adaletli ve koruyucu olduğunu açık bir şekilde göstermektedir. Büyük Selçuklu Devleti'nin Ulu Sultan $1 \mathrm{M}$ e li k ş a h'ın bir bedevî Arabın şikâyetini dinleyip suçlu bulunan bir Selçuklu askerini elini kestirerek cezalandırması, dikkate şayan bir olay olarak böylece tarihe geçmiştir.

Bu olaydan sonra Sultan Melikşah, Musul'dan ayrıldı (5 Ağustos 1086) ve halkının başvurusu sonucunda Urfa'yı ele geçirip Selçuklu sınırları içine aldı, bu arada Câber kalesi de ele geçirildi. Buradaki hırsız ve fesatçılanın başı olan bir adamın karısı, kalenin tepesine çıkarak kendini aşağı attı ise de sadece bacağı kırılıp ölümden kurtulmuştu. Bu olay sultana bildirilince sultan, o kadını yanına getirtip "Niçin canını böyle tehlikeye attun?" diye sorunca kadın da "Tecavüze uğramaktan korktuğum için canıma kıymayı yeğledim" dedi. Kadının bu cevabına çok şaşıran sultan, "Sen nerelisin?" diye sorunca o da "Dımaşklıyım" diye cevap verdi. Bunun üzerine sul$\tan$, "Bu kadının ailesine götürülüp teslim edilmesini" emretti ${ }^{16}$.

Görüldüğü üzere bu ilginç olay da Sultan M e li kş a h'ın, ülkesinde yaşayan insanların her türlü sorunlarıyla nasıl yakından ilgilendiğini ve onların güvenli ve mutlu olabilmeleri için ne kadar ince ve insaflı düşünüp gerekli kararları alarak emirler verdiğini bütün açıklığıyla göstermektedir.

Daha sonra Haleb'e gelen Sultan M e li ks a h'a bölgedeki çeşitli Selçuklu vasal emîrleri, birer birer gelip tâbiiyetlerini arz etmişlerdir. Haleb'de bir süre kalan Sultan Melikşah, buradan daha önce S ül e y m a n $\$$ a h tarafından fethedilen (12 Aralık 1084) Antakya'ya gitmiş (Aralık 1086) ve şehirdeki $S$ ü $l$ e y m a n ş a h'ın veziri $H$ a s a n b. T a h i r tarafından şehir dışında karşılanmıștır. Sultan, beraberindeki emîrlerden Alpoğlu Yağısıyan'ı bir miktar askerle şehir Şı hneliği'ne atadı ve vezir $\mathrm{H}$ a s a n'ı da Divan işlerini yürütmekle görevlendirdi. Daha sonra sultan, Samandağı (Süveydiye)'na kadar giderek $A k d e n i z ' e ~ u l a s ̧ t$. Denizi büyük bir heyecanla seyreden sultan, hükümranlığı altunda bulunan ülkelerin babası A $1 \mathrm{p} \quad \mathrm{A}$ rs 1 a $\mathrm{n}$ dönemindekinden daha

16 İlgili araşturmalarda yer almayan bu olay hakkında bk. A. Sevim, a.g.makl., s. 69 ve Ahmed b. Mahmud, I, s. 151. 
geniş bir hâle gelmesi nedeniyle T a n r r'ya şükretmiş, bu düşüncelerin kendisinde oluşturduğu gurur ve heyecanla atını dalgalı denize sürerek elindeki kılıcı üç kez sulara daldırıp çıkartmış ve "İşte T a n r ı, Doğu Denizi'nden Bat Denizi'ne kadar olan ülkelerin hâkimiyetini bana verdi" dedikten sonra da namaz kılarak kendisine ihsan ettiği bu lutf ve inayetten dolayı $\mathrm{T}$ a $\mathrm{n}$ r ı'ya şükretmiştir. Bu arada sultan, deniz kıyısından bir miktar kum almış ve daha sonraki bir zamanda babası A 1 p A r s l a n'ın Merv kentindeki mezarına gidip "Ey babam A l p A r s l a n, sana müjdeler olsun, henüz bir çocuk olarak bırakuğın oğlun, dünyayı baştan başa fethetti" demek suretiyle haklı ve gururlu duygularını belirtmiștir ${ }^{17}$.

\section{Sultan Melikşah'ın Bağdat'ı İkinci Ziyareti ve Cereyan Eden İlginç Olaylar}

Sultan $\mathrm{M}$ e li $\mathrm{k} \varsigma$ a $\mathrm{h}$, beraberinde veziri $\mathrm{N}$ i z a $\mathrm{m}$ ü $\mathrm{lm}$ ü l $\mathrm{k}$ olduğu hâlde, 5 Kasım 109l'de ikinci kez Bağdat'a geldi, kendisini Halifelik vezir vekili E mînü' d-d e vl e E b û S a 'd b. Mavsâlâ karşıladı. Sultanın bu gelişi sebebiyle kardeşi Suriye meliki Tutuş, Haleb emîri A k su ng u r, Urfa emîri B o z a n, emîr Ç u b u k ve diğer Selçuklu emîrleri Bağdat'a çağrılmışlardı. Sultanın Bağdat'a gelmesi dolayısıyla Bağdat'ta büyük şenlikler yapıldı. Bu cümleden olarak gece sohbeti yapılan Sümeyriyye gemilerinde ve büyük kayıklarda büyük mumlar yakıldı; her kayıta büyük bir çardak bulunuyordu. Böylece Dicle ırmağı meşalelerle süslendi. Bağdat halkı, bunu seyredip neşelenmek amacıyla evlerinden çıkarak Dicle ırmağı kıyısına gelip geceyi burada geçirdiler. Vezir $\mathrm{N}$ i z a m ü $1 \mathrm{~m}$ ü $1 \mathrm{k}$ ve diğer ileri gelen devlet adamları, bu ilginç manzara karşısında yapılan büyük gösterilere katıldılar, çeşitli eğlence ve oyunlar eşliğinde gemi ve kayıklarla Dicle ırmağında dolaştular; büyük gemilere odun doldurulup ateşler yakıldı. $\mathrm{Bu}$ arada Bağdat'ın batı kesimindeki halk, ellerinde birer, ikişer mum olduğu hâlde, Dicle ırmağının kıyısına indiler. Sultan Sarayı'nın (Dârü'l. memleke) damından Dicle ırmağına doğru birbirine sıkı sıkıya bağlanmış halatlar uzaniyordu. Bu siralarda da bir adam, ırmakta bulunan Sumeyriyye gemisine iplerle turmanır, orada ateş yakıp tekrar aşağı inerdi. Bu eğlenceler sırasında da Sultan M eli kşa h için Mîlâd (Doğum günü zamanı) ${ }^{18}$ töreni yapıldı. Dönemin şâirleri, bu gecede olup bitenleri yazdıkları şiirlerde de

\footnotetext{
${ }^{17}$ Bu hususta bk. A. Sevim, a.g.e., s. 129-131; krş. İ. Kafesoğlu, a.g.e., s. 93-94.

${ }^{18} \mathrm{Bu}$ sõzcük için bk $\dot{I} A$. "Mîlâd" mad.
} 
dile getirmişlerdir. Bu şâirlerden Ebu'l-Kas $1 \mathrm{~m}$ el-M u tarrız da bu hususta şöyle bir şiir yazmıştur:

Âşıların üstünde yanan her ateş,

Ya kalbinin ateşidir, ya da Sudak gecesinin ateşidir.

Zifiri karanlık, şafağın aydınlığına karışt....

Güneş, orada dolunayı ziyaret etti.

Yeryüzüne, kavuşma ve ayrilık yerlerinin arasına,

Kendi cevherlerinden bir örtü yaydı...

Iş̣ldayan kandiller gibiydi... Kovulmadan ve yanmadan

Gökyüzüne inmişti...

Ne tuhaf bir ateş! Rudvan, onu alevlendiriyor,

Mâlik ise ondan korkuyor!...

Cennet bahçelerinin kendisine gülümsediği

Bir mecliste dişleri, ışıl ışl parlyyor...

Mumların öyle gözleri var ki, şafă̆ın yıldızları,

Her bakışında onlardan dert yanıyor...

Üzerinde yaprak bulunmayan dal gibi salınan

İnce bellilerden ışılar saçılmaktadır.

Şaşıyorum doğrusu, yaşaması için boynunun vurulması

Gerektiği hâlde o, sakin bir şekilde ağlıyor ${ }^{19}$.

\section{Sultan Melikşah'ın Bağdat'taki İlginç Faaliyetleri}

Sultan M e l i kş a h, Bağdat'ta bulunduğu sıralarda, "Tuğrul Bey kentinde bulunan evine yakın bir yerde, bir şehir çarşısının yapılmasını" emretti. Sultanın bu emri üzerine tâcirler için hanlar ve içinde çeşitli malların bulunabileceği bir çarşı, yol ve sokaklar yapıldı. Sultanın eşi T e r k e n H a tu n da Dâru'd-darb (Darbhane) için güvenli bir hücre yaptırdı ve "Buralarda ticarî işlemlerin ancak altınlarla yapılmasını" halka yüksek sesle ilân ettirdi. Bu arada sultan, "Sultan Camii"nin yapılmasını ve bu camiin yapım giderlerinin tespit edilip bunların gümüş parayla ödenmesini” emretti. Bunun üzerine bu camiin yapımına derhal başlandı. Buranın gözcülerinden bir kısmının bütün ücretlerini bizzat sultan üzerine alıp ödedi, camiin inşasının denetim işlerine de Kadi'l-kudât E b û B e k r eş-

${ }^{19} \mathrm{Bu}$ hususta bk. İbnü'l-Cevzî, el-Muntazam fi Tarihi'l-mülûk ve'l-ümem Yay. Muhammed Abdülkadir Ata, Mustafa Abdülkadir Ata, indeks: İbrahim Şemseddin, Beyrut 1993-95, XVI, s. 294-95; İbnü'l-Esîr, el-Kâmil fi't-tarih (Beyrut 1966), X. s. 199; ḳ̛s. İ. Kafesoğlu, a.g.e., s. 123-25; A. Sevim-E.Merçil, a.g.e., s. 124-25. 
Şâ m î̀yi atadı. İnşa için gerekli olan tahta ve keresteleri de Sâmerrâ ${ }^{20} \mathrm{Cami}$ i'nden getirtti. Sultan, ayrıca Ebû Hanîfe Medrese ve Çarşısı'nı da yapturdı. Bu arada sultan, avladığı hayvanların boynuzlarından Kûfe'nin dışında bir Minare (Minaretü'l-kurûn) yapturdı. Bunun aynısını Mâverâünnehr'de de yapturdı. Rivayet edildiğine göre, bu hayvanları bizzat kendisi avlamış ve bunların sayısı da 10 bin imiş. Öte yandan vezir $\mathrm{N}$ i z a m ü $1 \mathrm{~m}$ ü $1 \mathrm{k}$ de Bustanü'l-cisr ve buna sınır olan hastahaneye ait vakıf topraklarını, 50 yıl süreyle kiraladı. $\mathrm{O}$, bütün bu işleri yoluna koymak ve bitirmek amacıyla kendini bir eve âdeta hapsetti. Bu arada Ebu'l-Has an el-Herevî, kendisine ait olan bir hanı $\mathrm{N}$ i z a m ül $\mathrm{m}$ ül k'e armağan etti, E b û $S a^{\prime} d$ el-Yahự̂ de bu hanın bakımını bizzat üzerine aldı. T âc ü $1 \mathrm{~m}$ ülk E b u' l-G a n â i m, Dârü'l-hemmâm'ı ve onun devamindaki Benü'l-Me'mun Kasrı'nı ve Hâc emîri K u tl u ğ'un evini satın aldı ve bütün bu binaların hepsini, Reîs E b û T â h i r İ b n ü' l-E s b â gî'yi görevlendirip tamir ettirdi ${ }^{21}$.

\section{Sultan Melikşah'ın Veziri Nizamülmülk'le Olan İlginç İlişkileri}

Sultan M e li kşa h 'ın 76 yll, 10 ay ve 19 gün yaşayan veziri $\mathrm{N}$ i z a m ü $1 \mathrm{~m}$ ü 1 k'ün ömrünün bu kadar uzun olmasından hoşlanmadığı, rivayet edilmiştir. Özellikle $N$ i z a m ü $1 \mathrm{~m}$ ü 1 k'ün düşmanları, onun devlete ait mal ve paralardan pek çoğunu almış olduğunu, sultana bildirmişler, işte bu nedenle de M e l i k ş a h, vezirinden hoşlanmamaya başlamıştı, hattâ bu husus, halk arasında bile yayılmışt. Bunun bir sonucu olarak sultan, $\mathrm{N} \mathrm{i} \mathrm{-}$ $\mathrm{z}$ a m ü $1 \mathrm{~m}$ ü $1 \mathrm{k}$ 'ün oğlu Ş e m s ü $1 \mathrm{~m}$ ü $1 \mathrm{k} O \mathrm{O} \mathrm{m}$ a n'ın valisi bulunduğu Merv kentine, değerli memlükü (yetiştirmesi) B e r d i (ya da K o d a n)'yi sılhne olarak atadı. Buna son derecede kızıp öfkelenen $\mathrm{O}$ s m a n, B e r d i'yi tutuklattı ise de bir süre sonra serbest bıraktı, o da yardım istemek amacıyla Merv'den ayrilıp sultanın yanına gitti. Bunun üzerine sultan, devletin ileri gelenlerini (erkân) yanına çăğırtıp onlara "Hâce $\mathrm{H}$ a sa n ( $\mathrm{N}$ i z a m ü $\mathrm{lm}$ ül k)'a gidin ve benim adıma ona, 'Sen, hükümdarlıkta benim ortağım mısın? Bu husus için bir karar gerektir. Yok eğer sen, bana tâbi bir durumda isen o takdirde haddinin gereğini yapman gerekir. Senin çocukların Selçuklu ülkesinin büyük bir bölümünün yönetimini kendi başlarına ele geçirmịş̧ durumda bulunuyorlar, hattâ onlar, bana karşı olan

${ }^{20}$ Abbasîlerin Elcezire'deki yönetim merkezi olùp bugün Bağdat'ın kuzeyinde ve Dicle ırmağı kyısında büyük bir harabe alanı (Bk. İA. "Sâmmerrâ" mad.).

${ }^{21}$ Bu konudaki bilgileri krş. İ. Kafesoğlu, a.g.e., s. 166 vd.; O. Turan, a.g.e., s. 87, 156. 
hürmet ve saygıdan ayrılmama hususunda ikna olunamadılar'" dedi. Bunun üzerine devlet erkânı, sultanın bu sözlerini aynen $\mathrm{N}$ i z a m ü $1 \mathrm{~m}$ ü 1 k'e ulaşturdıkları zaman $\mathrm{N}$ i z a m ü $\mathrm{l}$ m ü $\mathrm{l}$ k, onlara dedi ki "Sultana söyleyin: $\mathrm{O}$, devletin yönetiminde kendisinin ortağı olduğumu bilmiyor mu? $\mathrm{O}$, benim devlet yönetiminde aldığım önlemler sayesinde sultanlık makamına geldiğini ve babası öldürüldüğü zaman herkesin kendi aleyhine birleştiğini bilmiyor mu? O, ordusuyla Amuderya ırmağını geçip birçok memleket fethettiği zaman Selçuklu ülkesi, yükselmek için revaçta olanlarla korkudan ürkek bir duruma düşenler arasında, sadece benim aldığım yerinde ve yararlı önlemler sayesinde bu iyi duruma geldi. İște bundan sonra ona söyleyip bildiriniz ki hükümdarlık tâcının devamı, ancak vezirlik divitinin (hokka) benim elimde olmasına bağlıdır. Bu divit kapatıldığı takdirde o tâc da yok olur". N i z a m ü $1 \mathrm{~m}$ ü 1 k'ün bu sözleri sultana bildirilince sultan da vezir için bir takım önlemler almaya devam etti. Rivayet edildiğine göre, vezirin öldürülmesi, sultanın onayı ve $\mathrm{T}$ a c ü $1 \mathrm{~m}$ ülk $\mathrm{E}$ b u' $1-\mathrm{G}$ a n â i m'in girişimleri sonucunda olmuş ${ }^{22}$.

Yukarıda söz konusu edilenlere ilâve olarak Sultan M e li kş a h 'ın ilginç hâl ve davranışlarıyla ilgili kayıtları şöylece sıralayabiliriz:

1- Sultan M eli kşa h, fakirlere 10 bin altun tutarında sadaka verirmiş, bu nedenle de "Ben, her şeyden berî olan T a n r ı'dan korkarım" demiştir. Türk ülkelerinin en uzak yerinden Yemen'in en uzak yerlerine kadar olan memleketlerde adına hükümdar olarak hutbe okutulan Sultan M e likşah'a birçok hükümdarlar, mektuplar yazıp onunla ilişkiler kurmuşlardır. Sultan öldüğü zaman Bizans, Lân ${ }^{23}$, Hazar, Suriye, Yemen, Fars ve diğer memleket hükümdarları, taziyet için elçiler gönderdiler. Vezir $\mathrm{N}$ i z a m ü $1 \mathrm{~m}$ ü 1 k'ün söylediğine göre, eğer Sultan $\mathrm{M}$ e li ks a h, yılda 20 milyon altundan daha çok vergi toplatsaydı kendi döneminde bütün yollar güvence altunda olurdu. Onun hayır işleri yapmaktaki niyeti daima isabetli ve iyi olmuştur. $\mathrm{O}$, kadınlara ve güçsüz insanlara yardımda bulunur, onlara hep arka çıkardı ${ }^{24}$.

22 Sultan Melikşah-vezir Niza mülmülk ilişkileri hakkunda bk. A. Sevim, Biyografilerle Selçuklular Tarihi, İbnü 'l-Adîm, Bugyetü't-taleb fi Tarihi Haleb Seçmeler, Ankara 1989, TTK. yay., s. 42, 55-57, 36-61; İbnü'l-Cevzî, a.g.e., XVI, s.302-307; Ahmed b. Mahmud, Selçuk-Nâme, II, İstanbul 1977, s. 13-14. İ. Kafesoğlu, a.g.e, s. 198-206; O. Turan, a.g.e., s. 158160; A. Sevim-E.Merçil, a.g.e., s. 131-132; $I A$. "Nizamülmülk" mad.

${ }^{23}$ Bâbü'l-Ebvâb'a yakın olup Hazar Denizi'ne kadar uzanan büyük bir ülke (Bk. IA "Allân" mad.)

${ }^{24}$ İbnü'l-Cevzî, a.g.e., XVI.s.309. 
2- Tâcirlerden birisi, sultanla ilgili olarak şunları söylemiştir: Ben, bir gün sultanın ordugâhında idim. Sultan, bir gün ava çıkmak amacıyla atına bindi, yolda giderken ağlamakta olan bir köylüye rastladı ve ona "Ne oldu böyle sana?" deyince o da sultana "Ey haylbaşı(Suvari Komutanı) ${ }^{25}$, benim yanımda bir yük karpuzum vardı, ben, bunları satacaktım. Fakat bana rastlayan üç asker, bunları benden aldılar" dedi. Bunun üzerine sultan, ona "Ordugâha git, orada kırmızı bir kubbe var, orada otur ve akşama kadar oradan kalkma, ben, geri dönüp seni zengin edecek kadar ihsanlarda bulunacağım" dedi. Bir süre sonra sultan, avdan dönünce Şarabî (Şarabdâr) ${ }^{26}$ 'ye "Ben, karpuz istemiştim, bu nedenle askerleri ve otağlarını kontrol et!" dedi. Sultanın bu emri üzerine Şarabî, sultanın bu emrini derhal yerine getirdi ve ona karpuz getirdi. Sultan, hemen ona "Bu karpuzu kimin yanında gördün?" diye sorunca o da "Falan Hâcib'in otağında" dedi, sultan da "O Hâcib'i hemen bana getirin" dedi ve Hâcib de derhal sultana getirildi. Sultan, ona "Bu karpuz sana nereden geldi?" diye sorunca Hâcib, "Bunu bana askerler getirdi" dedi. Bunun üzerine sultan, "O askerleri hemen derhal istiyorum" deyince yapılan kötülüğü hisseden $H$ âcib, bunu askerlere bildirdi. Bunun üzerine öldürüleceklerini hisseden askerler, oradan derhal kaçıp uzaklaştılar, Hâcib ise geri dönüp sultana "Onlar, sizin kendilerini istediğinizi anladıkları için kaçmışlar" dedi. Bunun üzerine sultanın "O köylüyü bana getirin" demesi üzerine köylü derhal getirildi. Sultan, ona "Senin karpuzlarını, -Hâcib'i gösterip- bu adam mı aidı? diye sorunca köylü de "Evet" deyince sultan, ona "Bu Hâcib, babamın ve benim yetiştirmem (Memlûk)'dir, onu, benim sana bir ihsanım olarak teslim ediyorum. Fakat bu Hâcib, sana ait olan karpuzları senden alan askerleri buraya getirmedi. T a n r '’ya ant olsun ki sen, onu biraksan o takdirde senin boynunu kesinlikle vurdururum" dedi; bu nedenle köylü, Hâcib'in elini sıkıca tutup dışarı çıkarttı, daha sonra da Hâcib, köylüden canını 300 altına saun aldı. Daha sonra o köylü, dönüp sultana gelerek ona "Ey sultan, bana armağan olarak verdiğin o Hâcib, kendini 300 altuna benden satun aldı" dedi. Bunun üzerine sultan, ona "Sen buna razı misın?" diye sorunca o da "Evet" dedi, sultan da ona "O hâlde parayı al ve bizden memnun olarak buradan git!" dedi ${ }^{27}$.

\footnotetext{
${ }^{25}$ Bu kelime hakkında bk. A. Sevim-E.Merçil, a.g.e., s. 514.

${ }^{26}$ Sultanın içki ve şerbetlerini hazırlayan Şarabhane âmiri Bk. A.Sevim-E.Merçil, a.g.e, s. 506.

${ }^{27}$ Bu hususta bk. İbnü'l-Cevzî, a.g.e., XVI, s. 309. Burada verilen Sultan M e 1 i k şa h 'la ilgili bu ilginç kayıtlan krş. İbnü'l-Esîr, a.g.e., X, s. 211-12; Ahmed b. Mahmud, II, s. 23-24; ayrıca bk. A. Sevim-E.Merçil, a.g.e., s. 135.
} 
Bu ilginç kayıtlarda da Sultan M e li kşa h 'ın Selçuklu ülkesinde hiçbir kimsenin herhangi bir şekilde haksızlığa uğrayıp zarar görmemesi ve gördükleri takdirde de nasıl korunduğu hususunda ne kadar hassas bir tutum ve davranışlarda bulunduğu, bütün açıklığıyla görülmektedir.

3- Sultan M e l i kş a h, beraberindekilerle birlikte oldukça dar ve sarp bir yolda giderken beraberinde, üstünde mal yüklü katurlar bulunan bir tâcire rastladı. Sultanın yanında bulunan kimseler, kendilerine yol açmak amacıyla katurları, at üstünde bulunan tâcirin tarafına çekmeye başlayınca sultan, onlara "Öyle yapmayın, biz atların üstünde olduğumuz için kolaylıkla yukarı tepeye çıkabiliriz, fakat bu katırların üzerlerinde çok ağır yükler vardır, bu durumda onları yukarı tepeye çıkarmaya çalışmak, çok zor ve tehlikeli olur" dedi. Böylece sultan, beraberindekilerle birlikte tâcirin yükleriyle oradan geçip gidinceye kadar düz yola çıktu, daha sonra da geri döndü.

Daha sonra sultan, bu kez yürümekte olan bir kadına rastladı ve ona "Böyle yaya olarak nereye gidiyorsun?" diye sorunca kadın da "Hacca gidiyorum" diye cevap verdi. Bunun üzerine sultan, ona, "Nasıl olur da buna gücün, kuvvetin yeter?" diye sorunca kadın, "Ben, işte böyle yaya olarak Bağdat'a gidip oradan, sevap kazanmak için beni Hacca götürecek birisini bulacağım" dedi. Onun bu sözleri üzerine sultan, çantasında bulunan altınları çıkarıp kadının üzerindeki şala attı ve "Bunlarla kendine bir binek hayvanı satın al, geri kalanlan da senin gerekli giderlerine sarfet" dedi ${ }^{28}$.

Öteki ilgili kaynak ve araşurmalarda pek yer almayan bu kayıtlarda da Sultan M e li kş a h 'ın, güç durumlarda kalan kimselerle nasıl yakından ilgilenip onlara gerekli yardım ve destekleri yapmaktan geri kalmadığı, bütün açıklığıyla görülmektedir.

4- Sultan M elikşa h, isyan hâlinde bulunan T e ki ş'le savaşmak için harekete geçtiği sıralarda, Tus kentindeki A li b. M u s a e r-R 1 z a'nın türbesine (Meşhed) uğradı ve beraberindeki veziri $\mathrm{N}$ i z a m ü $1 \mathrm{~m}$ ü 1 k'le birlikte türbenin bulunduğu yere girdi ve duada bulundu; sonra sultan, vezirine, "Ey $\mathrm{H}$ a s a n, sen bu türbede ne için dua ettin?" diye sorunca vezir, "T a n r ı, seni kardeşine karşı başarılı kılsın diye duada bulundum" deyince sultan, "Ben 'T a n rı'dan bunu istemedim, ancak T a n r 1 m, eğer kardeşim, Müslümanlar için benden daha iyi hizmette bulunuyorsa onu, bana karşı 25.

${ }^{28}$ Bu ilginç kayıtlar için bk. İbnū'l-Cevzí, a.g.e., s. XVI, s. 310. Ahmed b. Mahmud, II, s. 24- 
başarılı kıl, yok eğer ben, Müslümanlara ondan daha iyi hizmet ediyorsam, o takdirde beni, onun karşısında başarılı kıl!" şeklinde dua ettim" dedi ${ }^{29}$.

Bu kısa kayıtta da ülkesinde yaşayan halka hizmet etme hususunda Sul$\tan \mathrm{M}$ e 1 i k ş a h'ın ne kadar güzel ve olumlu niyet sahibi olduğu, bütün açıklığıyla görülmektedir.

5- Bir Türkmen, beraberinde başka bir Türkmenle birlikte sultan M e 1 i k ş a h'a gelip "Bu adamın kızımla olan cinsî ilişkisini gözlerimle gördüm, onu öldürmem için bana izin vermenizi sizden istiyorum" deyince sultan ona, "Onu öldürme, biz, senin kızını onunla evlendiririz, mihrini de Devlet Hazinesi'nden karşılarız" dedi ise de Türkmen, "Onu öldürmekten başka hiçbir şeye razı olmam" dedi. Onun bu sözü üzerine sultan, "Bana bir kılıç getirin" dedi, kendisine hemen getirilen kılıcı kınından çıkaran sultan, şikâyetçi Türkmen'e "Gel" dedi. Buna herkes şaşırıp kaldı ve sultanın, kızın babasını öldüreceğini sandılar. Türkmen, kendisine yaklaşınca sultan, kılıcı ona verdi ve kınını kendi elinde tuttuğu kılıcı "Kınına sokmasını" emretti, fakat Türkmen, ne kadar çok uğraştıysa da sultan, ters çevirdiği kına, onun kılıcı sokmasına fırsat vermedi. İşte bu sırada da sultan, ona "Kılıcı niçin kınına koyamıyorsun?" diye sorunca Türkmen, "Ey sultan, sen, kılıcı kınına sokmama imkân vermiyorsun ki” diye cevap verdi. Bunun üzerine sultan, ona "İşte senin kızın da eğer istemeseydi o Türkmen, kızına yaptığı şeyi yapamaz, dolayısıyla da kızının ırzına geçemezdi. Eğer o Türkmeni öldürmek istiyorsan o takdirde kendi kızını da onunla birlikte öldür" dedi. Sultanın bu sözleri üzerine Türkmen, sultana cevap vermeyip yalnızca "Sultan ne emrederse o olur" demekle yetindi. Sultan da kadın ve Türkmenin nikâhını kıyacak kimseleri getirtip ikisinin nikâhını kıydırdı ve Devlet Hazinesi'nden de kadının mihrini verdi ${ }^{30}$.

6- Bir gün sultanın huzuruna bir vâiz gelip ona şu hikâyeyi anlattı:

Kisrâlardan (Eski İran hükümdarları) birisi, askerlerinden ayrı kalıp bir bostandan geçerken oradaki insanlardan içecek su istemiş. Küçük bir kız çocuğu da ona bir kap içinde, şeker kamışı suyu ve biraz da kar getirmiş, Kisrâ da onu içmiş ve çok beğenmiş, kız çocuğuna "Bu nasıl yapılıyor?" diye sorunca kız da ona "Bu, bizim burada yetişen şeker kamışından yapılır;

${ }^{29}$ İbnül'-Cevzî, gõst. yer. Bu ilginç kayıtan krş. İbnül'l-Esîr, a.g.e., X, s. 211.

30 Öteki ilgili kaynak ve araşurmalarda yer almayan Sultan M e li ks a h'm adalet uygulamasıyla ilgili bu ilginç kayıtlar için bk. İbnü'l-Cevzî, a.g.e., XVI, s. 310; Ahmed b. Mahmud, II, s. 25-26. 
kamışı ellerimizle sıkmak suretiyle işte bu suyu çıkarırız" cevabını vermiş. Bunun üzerine Kisrâ, "Ondan bana biraz daha getir" demiş, onun kim olduğunu bilmeyen kız, süratle harekete geçmiş. Bu arada Kisrâ da kendi kendine, bu bostanı satın almak için buranın tutarı olan parayı sahiplerine vermeyi tasarlamıs. Bir süre sonra kız, ağlayarak geri gelirken orada gördüğü, fakat tanımadığı sultan, ona "Neyin var senin?" diye sorunca kız da ona "Sultanımızın bize olan niyeti değişmiş" demiş. Bunun üzerine sultan, ona "Bunu nereden anladın?" deyince kız, "Ben, bu suyu zorlamadan sıkıp çıkarıyordum, fakat şimdi ne kadar uğraşumsa da bir türlü çıkaramadım” demiş. Sultan, onun doğru söylediğini anlamış, bu nedenle de ona, "Git ve yeniden sıkmayı dene, bu kez başarılı olup amacına ulaşacaksın" demiş ve kıza azmettiği şeyi yapabilmesine karar vermiş, böylece kız da kamışı sıkmayı başarmış ve güleç bir yüzle sultana geri gelmiş.

Vâiz, bu hikâyeyi anlatunca sultan, ona demiş ki "Bana bunları böyle anlatyorsun da halka neden bunları şöyle anlatmıyorsun?" : Kisrâ, yalnız başına bir bostandan geçerken bostan bekçisine, "Bana, bir salkım koruk ver, çünkü beni hararet bastı, bu sebeple de çok susadım" demiş. Bekçi de ona "Bunu yapamam, çünkü sultan bile gelip bundan hissesine düşeni almamıştr, bu nedenle ben, ona asla haksızlık edemem" demiş. Aralarında vezir N i z a m ü $1 \mathrm{~m}$ ü 1 k'ün de bulunduğu yerde hazır olanlar, Sultan M e li kş a h'ın vâizin söylediği o hikâyeye, söylediği bu hikâyeyle karşıllk vermesi üzerine hayrete düşmüşler ve bunu, onun güçlü zekâsına yormuşlardır ${ }^{31}$.

7- Sultan Melikşah, Isfahan'dan Antakya'ya, oradan da Bağdat'a gitmiş ve geçtiği bütün yerlerde askerlerinden hiçbirisinin halktan zorla, ya da haksız olarak herhangi bir şeyin aldığı asla rivayet edilmemiştir. Sultan, askerleriyle Bağdat'a her gelişinde halk, şehir içinde kıtlık ve dolayısıyla pahalılık olmasından endişeye kapılmışsa da ancak durum, sandıklarının tersine çıkmıștur; hattâ sıradan insanlar, gece, gündüz demeden onun askerlerinin arasına karışır, satıcılar da incir ve tavuk satmak için askerlerin arasında hiç korkup çekinmeden dolaşırlar ve istedikleri fiyatlardan satış yaparlardı. Bu arada sultan, gümrük harcını kaldırmak isteyince tahsildarlardan birisi, ona "Ey sultan, bu sayede, bu yll Devlet Hazinesi'nden 600 binden

31 Aynı şekilde ilgili kaynak ve araşurmalarda bulunmayan Sultan Melikşa h hakkındaki bu ilginç kayıtlar için bk. İbnü'l-Cevzî, a.g.e., XVI, s. 310-11; Ahmed b. Mahmud, II, s. 26-27. 
fazla alun eksiltmiş olacaksın" deyince sultan ona, "Para ve mal T a n r ı'ya aittir, kullar, onun kullarıdır, yeryüzü de onun ülkesidir, bu sebeple bu iş, böyle olacak. Bu sebeple her kim, böyle bir iş için bir daha bana gelecek olursa onun boynunu vurdururum" demiştir ${ }^{32}$.

8- Vâsıt'a bağlı büyük bir köy olan Haddâdiyye adlı köyden Gazzal'ın oğulları adıyla tanınan iki kişi, Sultan $\mathrm{M}$ e $\mathrm{l}$ i k ş a h 'ın yanına gelip atunın üzengisine yapışarak ona şunları söylediler: "Biz, $\mathrm{H}$ u $\mathrm{m}$ a r t e k i n el-H a l e b î'ye ıkta edilmiş olan Haddâdiyye köyündeniz. H u m a r t e k i n, bizim 1600 altınımıza el koyduğu gibi birimizin ön dişlerinden iki tanesini de kırdı, bu dişler, şu anda, onun avucunun içinde durmaktadır. Ey sultan, ondan bizim hakkımızı alman için sana geldik. Senin adaletin halk arasında çok yayıldı, bu sebeple biz de sana geldik. T a n r ı'nın sana yapılmasını farz kıldığı gibi, ondan hakkımızı alırsan ne âlâ, yok eğer bunu yapmazsan T a n r 1, aramızda adaletle hüküm verecektir." Bunun üzerine sultan, atından inerek onlara "Her biriniz, kolumun bir yeninden tutarak beni $N$ i z a m ü l m ü l k'ün evine götürünüz" deyince onlar, sultanın bu sözleri kendilerini ürkütüp korkuttuğu için onun bu isteğini yerine getirmeye cesaret edemediler. Fakat sultan, dediğini yapmaları için her ikisine ant içirince her biri, sultanın yeninden tutarak onu $\mathrm{N}$ i z a m ü $1 \mathrm{~m}$ ü $1 \mathrm{k}$ 'ün evinin kapısına kadar götürdüler. Kendisine, sultanın ve beraberindekilerin geldiğini haber alan $\mathrm{N}$ i z a m ü $1 \mathrm{~m}$ ü $1 \mathrm{k}$, süratle evinden çıkıp sultanın önünde yer öptü ve "Ey yüce sultan, neden böyle yapıyorsun?" diye sorunca sultan, ona şöyle dedi: "Yarın, T a n rı'nın huzurunda benden Müslümanların hakları sorulduğu zaman hâlim nice olacak. Seni, benim adıma bu görevi yerine getirmen için atamıştım. Halka bir zarar gelirse senin yüzünden gelir, muhatab sen olursun, bu nedenle işine iyi bakıp görevini yerine getir!" Bunun üzerine vezir, yer öpüp sultanın emrini yerine getirmek için derhal harekete geçti. Çok geçmeden sultan geri dönünce vezir, "H u m a r t e k i n'in azledilmesi, ıktânın elinden alınması, el koyduğu mal ve paraların sahiplerine geri verilmesi ve öne sürülen deliller ispatlandığı takdirde de $\mathrm{H} \mathrm{u} \mathrm{m}$ a r t e ki n'in iki dişinin sökülmesi için" bir ferman hazırladı. Bunun üzerine $\mathrm{N}$ i z a m ü $1 \mathrm{~m}$ ü 1 k'ün kendilerine 100 altın bağışladığı iki kişi, derhal oradan ayrıldılar ${ }^{33}$.

\footnotetext{
${ }^{32}$ Sultanın ordusundaki askerlerin nasıl bir disiplinle yetiştirildiğini ve sultanın adalet uygulamasını gösteren bu ilginç kaytlar için bk. göst. yer.

${ }^{33}$ Hibetullah b. Mubarek b. Yusuf un eserinden naklen İbün'l-Cevzî, a.g.e., XVI. s. 311-12; ayrıca bk. İbnü'l-Esir, a.g.e., X. s. 212-13; A. Sevim-E.Merçil, a.g.e., s. 134.
} 
9- Sultan M e likşa h Rey kentinde, huzuruna güzel bir şarkıcı kadını getirtmiş ve onun söylediği şarkıyı çok beğenmiş, canı onu arzulayınca kadın, ona "Ey sultan, ben, senin bu güzel yüzünün cehennem ateşinde azap görmesinden çekinirim. Helâl ile haram arasında bir tek sözcük var" demiş. Bunun üzerine sultan, ona "Doğru söyledin" dedikten sonra kadıyı çağırtarak bu şarkıcı kadını kendisiyle evlendirttirmiştir ${ }^{34}$.

10- Bir ara Bâtınî inancı, sultanın inancını bozmuşsa da sonradan o, inancını yeniden düzeltmiştir. Sultan M e l i k ş a h'ın yakınlarından olan Cürcanlı bir vâiz, sultanın inancı Bâtınîlikle bozuldu, hattâ daha da ileri giderek sultan, "T a n $\mathrm{r} 1$ nedir, T a n 11 diyerek ne demek istiyorsunuz?" demeye başladı. Ben de onun sorduğu bu soru üzerine şaşkına döndüm ve güzel bir cevap olarak sultana şunları yazıp bildirdim:

Şunu iyi bil ki ey hükümdar, bu avam tabakası ve câhiller, T a n rı'yı his yoluyla ararlar, o hissi yitirirlerse onu inkâr etmeye kalkarlar, bu da sağduyu sahipler için uygun bir durum olmaz. Bizim duygularımızın ulaşamadığı varlıklarımız vardır, akıl onları reddetmiyor. Akıl, onları ispat ettiği için onları inkâr etmek mümkün değildir. $O$ insanlardan birisi, sana "Gördüklerimizin dışında hiçbir şey, mevcut değildir" derse işte o zaman T a nrı'yı inkâr etmek, emir (buyruk) ve nehiy (men, yasak)'den pek hoşlanmayan câhil insanların içine nüfuz eder. Onlara göre, bizim için gelişip büyüyen ve ölümden sonra artık geri gelmeyecek olan uzun ve derin olan maddî bedenlerimiz vardır. Bu bedenler, gıdaları kabul edip alır, ondan güzel işler ortaya çıkar, meselâ up ve hendese gibi... Ve sonunda bütün bunların bu bedenlerin ötesindeki manevî bir şeyden ortaya çıktığını anlamışlardır; işte bu da ruh ve akıl'dır. Onlara "Bu iki şeyi duygularınızla mı idrak ettiniz?" diye sorduğumuz zaman onlar, "Hayır, onları, kendilerinden ortaya çıkan etkilerine deliller göstererek idrak ettik" derler. Biz de onlara 'T a n rı'dan rüzgârların ve yıldızların yaratılması, feleklerin yönetimi, ekin yeşertme, zamanı (devranı) çekip çevirme ortaya çıktı̆̆ı hâlde, onu hissetmeyi nasıl oldu da yitirdiniz? Bu bedenin nasıl bir ruhu ve aklı varsa, bu ikisi sayesinde mevcut ise bu ikisi hisle idrak edilemeyip aklî deliller, buna tanıklık ediyorsa işte her şeyden berî olan Yü c e Tanrı'nın da bu yaptıklarını hisseden akıl sayesinde varlığı sâbittir" dedik. C ü r c a n l 1 vâiz'in kendisine yazıp bildirdiği bu sözleri beğenen ve bundan dolayı duygulanan

${ }^{34}$ Ôteki ilgili kaynak ve araşturmalarda yer almayan bu õzel ve ilginç kayıt için bk. İbnū'lCevzî, a.g.e.. XVI., s. 313; Ahmed b. Mahmud, II, s. 29. 
Sultan M e li kşa h, Bâtınîleri lânetlemiş ve onun kendisine yazdığı şeylerin gerçekleri ortaya koyduğunu anlamışur ${ }^{35}$.

11- Bilindiği üzere vezir $\mathrm{N}$ i z a m ülm ül k'ün Nihavend yakınlarındaki Sihne'de konaklamakta iken E b û T â h i r adlı bir Bâtunî, elinde bir dilekçeyle onun yanına gelip dilekçeyi ona verdi, vezir de bunu okurken Bâtınî, elindeki bıçakla veziri ağır bir şekilde yaraladı. Bunu haber alan Sultan M e 1 i ks a h, Bağdat'taki evine yaralı olarak getirilen $\mathrm{N}$ i z a m ü $1 \mathrm{~m}$ ü 1 k'ün yanına derhal geldi. Bunun üzerine vezir, ona "Ey âlemin (dünyanın) sultanı, ben, babanın ve senin devletinde yaşlandım. Bana biraz zaman verseydin -çünkü ömrümden ancak az bir zaman kaldı- ya da beni vezirlikten uzaklaştursaydın da bana böyle sûikast yapılmasını emretmeseydin" dedi. Bunun üzerine sultan, hep boynuna asarak taşıdığı bir Kur'an'ı çıkarıp bu sûikast işinden haberi olmadığı ve bir emir vermediği hususunda ant içti ve "Ben, bu işe nasıl razı olup reva görürüm. Oysaki sen, benim devletimin bereketisin ve babam yerindesin" dedi $^{36}$.

Bilindiği üzere Sultan M e li kşa h, Bağdat'ta iken ava çıktığı sıralarda hastalanmış ve Bağdat'a döndükten sonra da 38 yaşında hayatını kaybetmiştir (19 Kasım 1092). Cesedi, İsfahan'a götürülüp oradaki kendi medresesinde bulunan türbesine defnedilmiştir ${ }^{37}$.

Sınırları, Cin sınırından Marmara Denizi'ne, Kafkaslar'dan Yemen, Aden ve Mısır sınırlarına kadar uzanan Büyük Selçuklu Devleti'nin en büyük hükümdarı olan Sultan M e likşa h, ülkede yaşayan Müslüman ve Müslüman olmayan halklara karşı din ve mezhep farkı gözetmeksizin -daha önce birçok kez değinildiği üzere- daima hoşgörülü bir şekilde haksızlığa ve dolayısıyla zarara uğramamaları için gerekli önlemleri aldırmış ve tabîi bunun bir sonucu olarak da bütün Selçuklu ülkesinde huzur ve sükûnu sağlamıș, bu sebeple Âdil Sultan lâkabıyla anılmıştır ${ }^{38}$.

35 Yine ilgili diğer kaynak ve araşurmalarda yer almayan bu ilginç kayıtlar için bk. E bu 'l-V ef â b. U k a y l'den naklen İbnü'l-Cevzî, a.g.e., XVI, s. 312-13.

${ }^{36}$ Bk. Biyografilerle Selçuklular Tarihi, s. 57, 59; ayrıca bk. İ. Kafesoğlu, a.g.e., s. 198-206; O. Turan, a.g.e., s 158-60; A. Sevim-E.Merçil, a.g.e., s. 131-32; $I A$. "Nizamülmülk" mad.

${ }^{37}$ Sultan $\mathrm{M}$ e li k s a h'ın hükümdarlık dönemi ve tarihî kişiliği hakkında ayrıntılı bilgiler, İ. Kafesoğlu'nun adı geçen eserinde yer almaktadır. Ayrıca bk. O. Turan, a.g.e., s. 159162; A. Sevim-E. Merçil, a.g.e., s. 133-36 ve bu eserlerdeki geniş bibliyografya.

${ }^{38}$ Bu konuda ayrıntulı bilgi için bk. İ. Kafesoğlu, a.g..e, s. 204 vd.; O. Turan, a.g.e., s. 16062; A. Sevim-E.Merçil, a.g.e., s. 133-36. 
